\title{
Symposium review: Integration of postweaning nutrient requirements and supply with composition of growth and mammary development in modern dairy heifers*
}

\author{
M. E. Van Amburgh, ${ }^{1}$ † F. Soberon, ${ }^{2}$ M. J. Meyer, ${ }^{1}$ and R. A. Molano ${ }^{1}$ \\ ${ }^{1}$ Department of Animal Science, Cornell University, Ithaca, NY 14853 \\ ${ }^{2}$ Nutreco USA, 115 Executive Drive, Highland, IL 62249
}

\section{ABSTRACT}

To optimize first lactation and lifetime milk yield, growth benchmarks were established to help meet the appropriate growth objectives of breeding weight and age at an economically viable time and to achieve the optimum body size and composition at first calving. These guidelines provide a framework that helps to minimize overfeeding and, thus, potential overconditioning of heifers, which can lead to postpartum metabolic issues and reduced milk yield. Concerns still exist that mammary development is impaired when body weight gain exceeds a certain threshold, which would negatively affects milk yield. The objective of this review was to integrate concepts of nutrient requirements, body growth and composition, mammary development, and milk yield to provide a systems-based perspective on first-lactation milk differences that have been associated with mammary development. Work in the early 1980s described the effect of high energy intake on mammary development and the relationship with circulating growth hormone linked the relationship between prepubertal growth, mammary development, and future milk yield. The primary outcome of that research was to provide an intuitive mechanism to explain why rapid growth during the prepubertal phase resulted in reduced milk yield. The observation of reduced mammary development could be repeated in almost every experiment, leading to the conclusion that high energy intake and increased average daily gain reduced mammary development through altered hormone status or some signaling processes. However, further work that looked at mammary development over the entire prepubertal growth phase recognized that mammary development was not reduced by high

Received June 24, 2018.

Accepted November 8, 2018.

*Presented as part of the Growth and Development/Ruminant Nutrition Symposium: Post-Weaning and Beyond at the ADSA Annual Meeting, Knoxville, Tennessee, June 2018.

†Corresponding author: mev1@cornell.edu energy intake, and instead accumulated at a constant rate; thus, overall mammary parenchymal growth was a function of the time to reach puberty and the associated signals to change from allometric mammary growth. The mammary gland, similar to most reproductive organs, grows in proportion to the size of the body and not in proportion to nutrient intake during the postweaning, prepubertal phase. First-lactation milk yield, mammary development, and body composition will be further discussed in the context of mechanisms and opportunities.

Key words: heifer, mammary development, nutrient requirements

\section{INTRODUCTION}

The growth of dairy replacement animals has several objectives, including low cost and a low number of days of nonproductive life, adequate body size, appropriate body composition, and capacity for optimum milk yield over their lifetimes associated with a long productive life. Actual growth objectives are a function of several factors, such as mature body weight (MBW), BW at calving, and calving age; these factors optimize costs as well as nutrients partitioned to growth during lactation, thus allowing for optimum milk yield and a prospective decision concerning the age at first calving (Hoffman et al., 1996; Fox et al., 1999). The integration of those factors provides the target growth rate necessary to meet the BW goal for first parturition within the stated amount of time, which then determines the nutrient supply required daily to meet the objectives.

Overall, changes in body chemical composition are affected by an increased level of nutrient intake above maintenance energy requirements, maturity, or both, which results in the dilution of empty body ash, water, and CP by fat (Reid et al., 1968; Garrett, 1987). This is because the chemical composition of the fat-free matter is largely unresponsive to $\mathrm{BW}$ or level of nutrient intake (Reid et al., 1968; Fortin et al., 1980; Garrett, 1987; Waldo et al., 1997). Furthermore, it is the retention 
rate of body $\mathrm{CP}$ relative to body fat, which decreases with increasing $\mathrm{BW}$ and increasing level of nutrient intake, that limits CP composition of the empty body. Data suggest that the rate of protein synthesis becomes limiting in cattle beyond a certain energy intake and growth rate; therefore, energy not deposited as protein is deposited as fat, and this breakpoint appears to be at approximately 1 to $1.1 \mathrm{~kg} / \mathrm{d}$ gain and is most likely MBW dependent (Byers, 1982).

The current Dairy NRC (2001) recommendations for nutrient requirements of growing Holstein heifers are based largely upon a data set collected from beef breeds (Garrett, 1980). With the exception of data collected at Cornell in the 1950s and 1960s (Fortin et al., 1980), little serial harvest data existed that described the composition of retained tissue in the growing Holstein heifer. Since publication of the Dairy NRC (2001), the chemical growth of both preweaning and prepubertal dairy breed heifers has received considerable research interest (Diaz et al., 2001; Tikofsky et al., 2001; Meyer, 2005; Bartlett et al., 2006; Bascom et al., 2007; Stamey et al., 2012). Further, research has been conducted to evaluate the effects of diet, nutrient intake, or both, on the composition of retained tissue between approximately 100 (Moallem et al., 2004) or $180 \mathrm{~kg}$ of BW (Waldo et al., 1997) and puberty in Holstein heifers. The data of Waldo et al. (1997) suggested that the composition of Holstein heifers contained less body fat than previously described and that this observation might be due to changes in mature size associated with selection for milk yield.

Further, data published over $40 \mathrm{yr}$ suggested that milk yield was reduced as prepubertal ADG increased, especially if the associated energy intake allowed for increased adipose deposition in the animal. Swanson (1960) was the first to publish data demonstrating that, as energy intake increased, fat deposition increased in the heifer, milk yield was reduced, and fatty infiltration of the mammary gland was likely the causative factor. This observation lead to much more work investigating mammary development and growth rate with the objective of understanding why a high growth rate reduced mammary parenchymal development (Sejrsen et al., 1982; Petitclerc et al., 1984; Mäntysaari et al., 1995). The data from Waldo et al. $(1997,1998)$ and Capuco et al. (1995) were the first to quantitatively integrate body growth, mammary development, and milk yield and included observations that were not consistent with the previously held perspective that decreased prepubertal mammary development negatively affected milk yield; however, this information was largely ignored.

This review will integrate concepts of body growth, composition, and nutrient requirements along with mammary development and first-lactation milk yield to provide a systems-based approach to describe the effects of incorrect body growth on first-lactation milk production that has been associated primarily with mammary development. The purpose of this review is to describe nutrient requirements and body composition and discuss how the stage of maturity and the rate of gain at each stage of physiological development can result in changes in body composition that help explain the milk yield observed in previously published studies. This information can be used to reduce total replacement raising cost and improve lactation performance by promoting growth at each stage of maturity while considering the body composition of the animals at calving, which allows for the optimization of firstlactation milk production while reducing the nutrient demand for growth during lactation.

\section{GROWTH OBJECTIVES}

The goals for raising replacement heifers go beyond achieving a specific weight gain. Given that they are future dairy cows, the goal of heifer rearing should be to optimize their future milk production potential. Body composition is directly related to growth rate, diet composition, and stage of chemical maturity relative to MBW at the time the growth occurred. With this in mind, it is vital to remember the effects of body condition or body composition at calving on milk yield. The effect of a higher degree of fatness or greater body condition on performance of dairy cattle was reported as a linear decrease in milk yield (Swanson, 1960; Garnsworthy and Topps, 1982), suggesting that as body fat or BCS increased by calving, milk yield was inversely related. Other data have refined this observation and associated it with reduced DMI; furthermore, this is the focus of much research into transition cow metabolism, insulin resistance, and the interaction between obesity and milk yield (Ingvartsen and Andersen, 2000; Douglas et al., 2006; Overton, 2011; Rico et al., 2015). Thus, when evaluating the data integrating prepubertal growth rates, mammary development, and milk yield, it is essential to understand the body composition of the heifer at calving when comparing studies related to milk yield. A heifer that is too light in BW will prioritize the partitioning of nutrients to growth at the expense of milk yield, whereas a more obese heifer will have similar postpartum metabolic responses as mature cows that calve with a higher BCS and body fat content. The targets for $\mathrm{BW}$ at various stages of growth were described in the 2001 Dairy NRC and the postcalving BW target was established at $85 \%$ of MBW (NRC, 2001). The original target BW postcalving was $82 \%$ of MBW (Van Amburgh et al., 1998); thus, anywhere in that range is likely acceptable to optimize 
first-lactation milk yield and minimize the partitioning of nutrients to growth.

\section{Maintenance Requirements}

The energy cost of maintenance must be described and accounted before calculating the energy available for growth. Recent work has suggested the maintenance requirements of dairy calves are similar to previous calculations, such as those suggested by Toullec (1989) and the Dairy NRC [2001; 0.1 Mcal of ME/kg of metabolic BW $\left.\left(\mathrm{BW}^{0.75}\right)\right]$, except for Jersey calves, which were estimated to have a requirement approximately $20 \%$ greater than Holsteins due to the body surface area to weight relationship (Van Amburgh and Drackley, 2005; Bascom et al., 2007). As the birth weight of any calf decreases, the maintenance requirements will increase accordingly, as the surface area to BW relationship will cause greater heat loss. Through weaning and in the ruminant state, the calculations for maintenance were calculated using the data from Meyer (2005) and Stamey et al. (2012). This data included 91 Holsteins from the 2 experiments and, using regression approaches similar to Lofgreen and Garrett (1968), the intercept was $73 \mathrm{kcal}$ of $\mathrm{NE}_{\mathrm{M}} / \mathrm{kg}$ of $\mathrm{BW}^{0.75}$ on an empty body weight (EBW) basis; considering an efficiency of use of $\mathrm{ME}$ of 0.63 , the maintenance requirement was 116 $\mathrm{kcal}$ of $\mathrm{ME} / \mathrm{kg}$ of $\mathrm{BW}^{0.75}$ on an EBW basis (Figure 1). This value is higher than that resulting from the Dairy NRC (2001) using a basal metabolism coefficient of 86 $\mathrm{kcal} / \mathrm{kg}^{0.75}$ on a live BW basis and an efficiency of use of ME for maintenance of 0.64. However, when converting the estimated coefficients to live BW, assuming EBW being $85 \%$ of live weight, the ME maintenance requirement would be $98 \mathrm{kcal} / \mathrm{kg}^{0.75}$ of live $\mathrm{BW}$, nearly identical to that reported by Moe (1981) for nonlactating dairy cattle. Overall, the maintenance requirements of the preweaning calf are well described and consistent among data sets and in current nutrient requirement publications. Calculations made with the available data set suggest that maintenance requirements for the ruminant heifer are being overestimated by up to $30 \%$. This aligns with previous observations made by Shamay et al. (2005), indicating that the NRC (2001) model estimated higher energy requirements than the energy consumed for the observed weight gains. Other nutritional systems (INRA, 1989; Alderman and Cottrill, 1993) use lower basal metabolism coefficients than the current dairy NRC.

\section{Body Composition and Requirements}

The same data set used to describe the maintenance requirements of calves and heifers is also a unique and significant data set describing changes in body composition of dairy replacement heifers (Waldo et al., 1997; Diaz et al., 2001; Tikofsky et al., 2001; Blome et al., 2003; Meyer, 2005; Bartlett et al., 2006; Bascom et al., 2007; Stamey et al., 2012). This data set also provides the capacity to evaluate the nutrient requirements of dairy replacement heifers.

The data have been evaluated and compared with existing data sets and, although beyond the scope of this review, a few observations of interest related to body composition, tissue energy, and efficiencies will be discussed. Overall, the data from the body composition data of Meyer (2005) and Stamey et al. (2012) demonstrate that during the early postweaning period, the tissue energy content of the gain is lower than at any other point in the growth period, which is most likely related to several factors (Figure 2). The first condition most likely relates to the type of tissue being retained, and in this case the rumen and gastrointestinal tract as a whole would be the primary tissue gaining the most mass as the heifers adapts to the consumption and digestion of solid feed (Baldwin et al., 2004). The development of these tissues requires a significant amount of nutrients, particularly protein. In fact, only during this stage of development does the energy re-

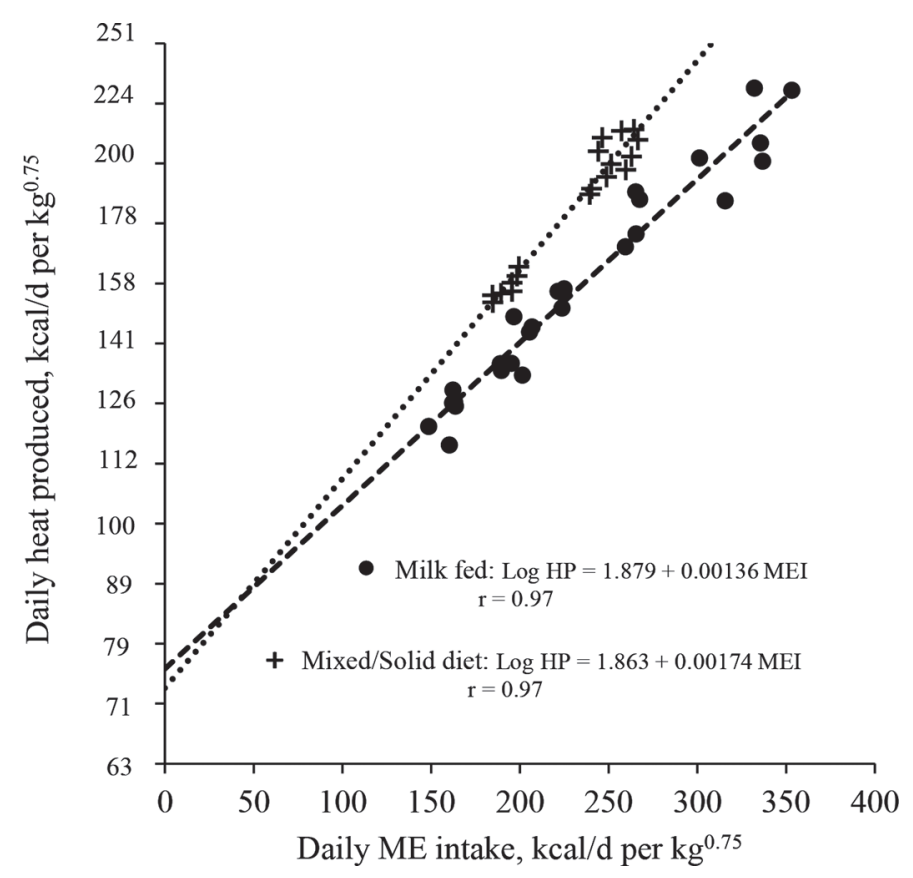

Figure 1. Determination of fasting heat production (HP) of Holstein heifers. Each point represents a treatment mean. Data for calves fed milk only came from 4 studies (Diaz et al., 2001; Tikofsky et al., 2001; Bartlett et al., 2006; Mills et al., 2010), with 27 treatments and 155 animals total. Data for heifers fed milk and solid feed or solid feed only came from 2 studies (Meyer, 2005, and Stamey et al., 2012), with 18 treatments and 91 animals total. MEI $=$ ME intake. 
tained as protein tissue account for the majority of the total retained energy and the protein retained in blood and organs reach its maximum, representing $24 \%$ of the total retained protein, which ranges between 14 and $20 \%$ in the other stages (Meyer, 2005; Stamey et al., 2012). Another factor affecting the content of energy in the tissue during early weaning would be the energy intake above maintenance. When reducing nutrients from liquid feeds in an effort to accommodate weaning, the amount of energy available above maintenance is generally reduced; thus, fat deposition would be low and energy content of the tissue being deposited would be low, which can be observed in the data described in Figure 3. As the animals progress toward puberty, it is obvious that the amount of energy retained per unit of EBW gain increases significantly, which is in keeping with the concept that fat deposition increases with both growth rate and maturity (Figure 2).

Consistent with the increased energy retained per unit of gain are the data described in Figure 3, where the protein retention per day is relatively flat from preweaning to approximately $250 \mathrm{~kg}$ of $\mathrm{BW}$, averaging 180

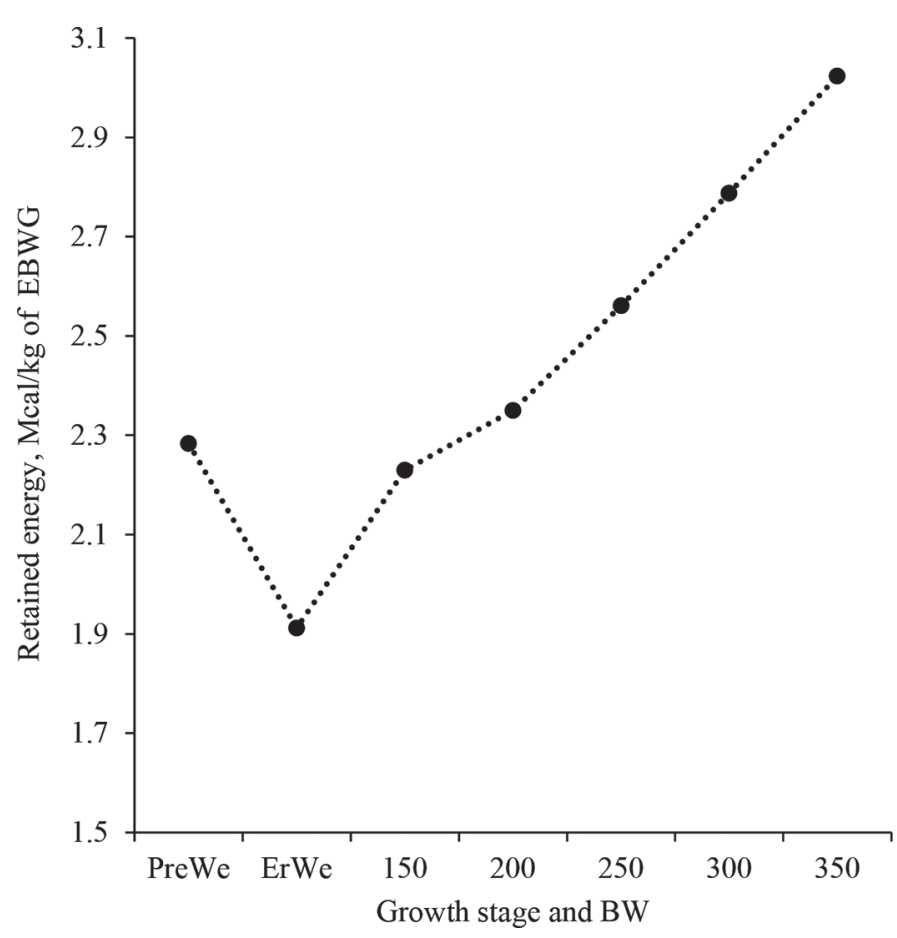

Figure 2. Retained energy in empty BW gain (EBWG) during different stages of growth of dairy heifers. PreWe = preweaning period including data from calves fed milk only (Diaz et al., 2001; Tikofsky et al., 2001; Bartlett et al., 2006; Mills et al., 2010) or liquid and solid feed (Stamey et al., 2012); ErWe = early postweaning phase of calves fed liquid and solid feed (Meyer, 2005; Stamey et al., 2012); 150 to 350 $=\mathrm{BW}$ in $\mathrm{kg}$ (Meyer, 2005).

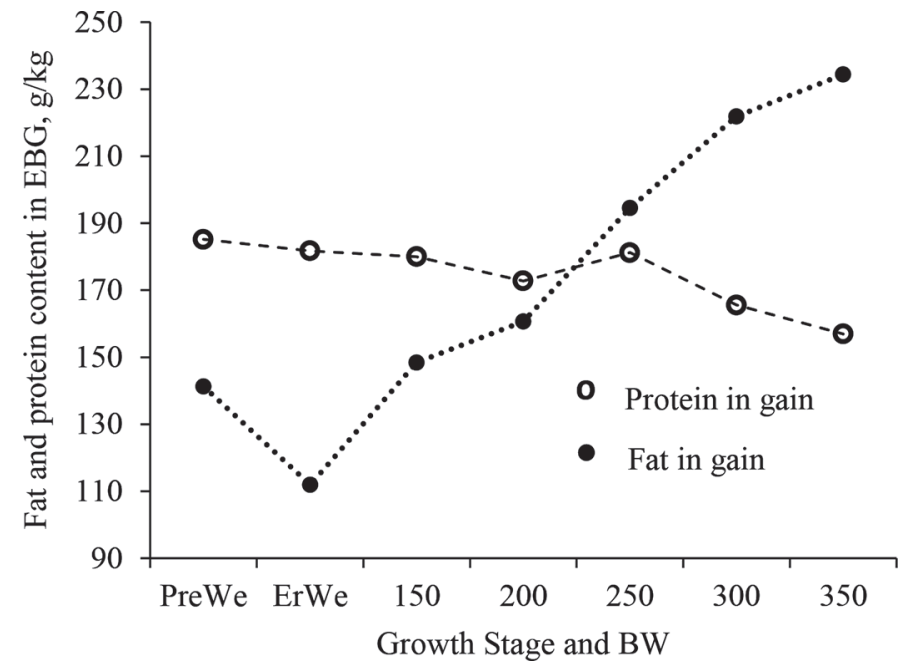

Figure 3. Protein and fat contained in empty body gain (EBG) during different stages of growth of dairy heifers. PreWe $=$ preweaning period including data from calves fed milk only (Diaz et al., 2001; Tikofsky et al., 2001; Bartlett et al., 2006; Mills et al., 2010) or liquid and solid feed (Stamey et al., 2012); ErWe = early postweaning phase of calves fed liquid and solid feed (Meyer, 2005; Stamey et al., 2012); 150 to $350=\mathrm{BW}$ in $\mathrm{kg}$ (Meyer, 2005).

$\mathrm{g} / \mathrm{kg}$ of EBW gain, whereas fat deposition was low during the transition phase and increased steadily as the animal grew. Thus the retained energy increased due to the change in fat deposition while protein retention was relatively constant.

Furthermore, this change in the composition of gain is relevant when estimating nutrient requirements for growth because it determines the efficiency of use of ME for body gain $\left(\mathbf{k}_{\mathbf{g}}\right)$. Protein deposition has a higher energetic cost than fat because the accumulation of protein represents the net balance between the continuous processes of synthesis and breakdown (Thorbek, 1977; Moe, 1981). Thus, $\mathrm{k}_{\mathrm{g}}$ decreases as protein in the gain increases and increases as the proportion of fat in the gain increases. Using the available data set, net $\mathrm{k}_{\mathrm{g}}$ was calculated for the different stages over the course of development and compared with the estimates obtained using the approach proposed by Williams and Jenkins (2003), which assumes partial net efficiencies of ME of 0.2 and 0.75 for protein and fat gain, respectively (Table 1 ). Before weaning, $\mathrm{k}_{\mathrm{g}}$ is high compared with the subsequent periods, and is the lowest right after weaning, which aligns with the composition of gain previously discussed for this transitional period. Ruminant heifers use ME for growth at an efficiency of 0.4 , which remains fairly constant further in development. Predicted $k_{g}$ aligned closely to the observed values, except in the preweaning period for which it was largely underestimated. This discrepancy could be 
due to the difference in efficiency of retaining energy as protein in nonruminants, which is more than double than that in ruminants (Thorbek, 1977; Williams and Jenkins, 2003).

Although the protein content of gain decreases with increasing BW and empty body gain when expressed as a percent of the gain, the absolute protein requirement does not necessarily change (Figure 3 ). The equation to predict net protein requirements (equation 1 ) used in the NRC (2001) accounts for this relationship, where the maximum amount of protein that can be retained is $268 \mathrm{~g} / \mathrm{d}$ and is then adjusted down as the energy content of the gain increases and fat displaces the protein, as shown in Figure 3:

$$
\mathrm{NP}_{\mathrm{g}}=\mathrm{SWG} \times\{268-[29.4 \times(\mathrm{RE} / \mathrm{SWG})]\},
$$

where $\mathrm{NP}_{\mathrm{g}}$ is retained protein in $\mathrm{g} / \mathrm{d}$; SWG is the shrunk weight gain in $\mathrm{kg} / \mathrm{d}$; and $\mathrm{RE}$ is retained energy in Mcal/d. The intercept of $268 \mathrm{~g}$ represents the maximum amount of protein that can be retained if all of the gain as energy was retained as protein, and this is then modified by the amount of $\mathrm{RE}$ and the relationship to SWG as the animal consumes more energy above maintenance and approaches MBW. As the heifers approach puberty, the tissue protein retained decreases by approximately $30 \mathrm{~g} / \mathrm{d}$ while energy content of the gain continues to increase, consistent with all other body composition data sets.

As nutrient requirements change with maturity, it becomes apparent that the requirements for energy and protein are a function of the stage of maturity and the rate of gain of the animal at a particular weight (Lofgreen and Garrett, 1968; Garrett, 1987; Fox et al.,

Table 1. Calculated and predicted net efficiency of ME utilization for growth $\left(\mathrm{k}_{\mathrm{g}}\right)$ during different stages of growth of dairy heifers

\begin{tabular}{lcc}
\hline & \multicolumn{2}{c}{$\mathrm{k}_{\mathrm{g}}$} \\
\cline { 2 - 3 } Stage of growth $^{1}$ & Observed & Predicted $^{2}$ \\
\hline Preweaning & 0.55 & 0.34 \\
Early postweaning & 0.28 & 0.31 \\
$150 \mathrm{~kg}$ & 0.39 & 0.35 \\
$200 \mathrm{~kg}$ & 0.40 & 0.36 \\
$250 \mathrm{~kg}$ & 0.40 & 0.38 \\
$300 \mathrm{~kg}$ & 0.40 & 0.40 \\
$350 \mathrm{~kg}$ & 0.41 & 0.42 \\
\hline
\end{tabular}

${ }^{1}$ Preweaning period included data from calves fed milk only (Diaz et al., 2001; Tikofsky et al., 2001; Bartlett et al., 2006; Mills et al., 2010) or liquid and solid feed (Stamey et al., 2012); early postweaning phase included data of calves fed liquid and solid feed (Meyer, 2005; Stamey et al., 2012); 150 to $350 \mathrm{~kg}$ of BW (Meyer, 2005).

${ }^{2}$ Using the equation $\mathrm{k}_{\mathrm{g}}=0.75 /\left(1+2.75 \times \mathrm{RE}_{\mathrm{p}} / \mathrm{RE}\right)$, where $\mathrm{RE}_{\mathrm{p}}$ is retained energy as protein and RE is retained energy. Williams and Jenkins (2003).
1999). The mature size of the animal is one of the primary factors affecting the expected growth rate, as the animal will partition nutrients to achieve its mature size assuming adequate nutrients above maintenance are supplied throughout the growth period. The current equations for energy and protein retention do an adequate job of describing the requirements for growth as long as the mature size is appropriately described. This approach was described by Fox et al. (1999) using the medium-framed steer $(478 \mathrm{~kg})$ from the Beef NRC (1996) as the standard reference animal to scale composition for adjustment of requirements for any given mature size and adopted by the Dairy NRC committee (NRC, 2001). The following example is based on calculating net energy retained using the equations:

$$
\mathrm{NE}_{\mathrm{G}}=0.0635 \times \mathrm{EQEBW}^{0.75} \times \mathrm{EBG}^{1.097},
$$

where $\mathrm{NE}_{\mathrm{G}}$ is in Mcal/d, EQEBW is the equivalent $\mathrm{EBW}$ in $\mathrm{kg}$, and EBG is empty body gain in $\mathrm{kg} / \mathrm{d}$; and

$$
\mathrm{EQSBW}=\mathrm{SBW} \times(478 / \mathrm{MSBW}),
$$

where EQSBW is equivalent shrunk BW; $\mathrm{SBW}$ is the actual shrunk BW; and MSBW is mature shrunk BW, all in $\mathrm{kg}$.

The following example is designed to illustrate the nutrient requirements of the animal with and without accounting for the composition of gain based on stage of maturity, using the standard reference weight animal and applying the target growth system (Fox et al., 1999; NRC, 2001). There are 2 requirements to use the target growth system: the MBW of the herd (or population of animals the requirements are being developed for) and the expected or proactively determined age at first calving. This then sets up the target growth rate, as it is expect that the animal weighs between 82 and $85 \%$ of MBW postcalving and pregnancy is achieved between 55 and $60 \%$ of MBW (Van Amburgh et al., 1998; NRC, 2001). For this example, the current group of animals are postweaning, weighing $84 \mathrm{~kg}$, and the mature size animals are $641( \pm 57) \mathrm{kg}$ with a target age at first calving (AFC) of 23 mo. This leads to a breeding and pregnancy weight of $353 \mathrm{~kg}(641 \times 0.55)$, from which the ADG can be calculated as

$$
(353 \mathrm{~kg}-84 \mathrm{~kg}) /(407 \mathrm{~d}-77 \mathrm{~d})=0.87 \mathrm{~kg} / \mathrm{d} .
$$

For the example, a mean BW is assumed with the following calculation $(353+84) / 2=218.5 \mathrm{~kg}$; thus, the gain requirement of $0.87 \mathrm{~kg} / \mathrm{d}$ is applied to animals weighing approximately $219 \mathrm{~kg}$. The shrunk BW, which represents the fasted $\mathrm{BW}$, is defined as the $96 \%$ of the 
live BW; therefore, mean and mature shrunk BW are 210 and $615 \mathrm{~kg}$, respectively. The next step is to adjust the composition of the animal using the standard reference animal to achieve an equivalent shrunk body weight (EQSBW) and the following equations used in these calculations are from the Dairy NRC (2001):

$$
(478 \mathrm{~kg} / 615 \mathrm{~kg}) \times 210 \mathrm{~kg}=163 \mathrm{~kg} .
$$

The energy equation was developed on an EBW (the weight of the animal minus the gastrointestinal contents) basis, which requires the use of the coefficient 0.891 to obtain an equivalent empty body weight (EQEBW):

$$
163 \mathrm{~kg} \times 0.891=145 \mathrm{~kg} .
$$

The next step is the empty body gain calculation that uses a 0.956 factor:

$$
(0.87 \mathrm{~kg} / \mathrm{d} \times 0.956)=0.83 \mathrm{~kg} / \mathrm{d} ;
$$

and then the calculation for the $\mathrm{NE}_{\mathrm{G}}$ can be made as

$$
0.0635 \times 145^{0.75} \times 0.83^{1.097}=2.16 \mathrm{Mcal} / \mathrm{d} .
$$

Thus, the average animal in the group, gaining 0.87 $\mathrm{kg} / \mathrm{d}$ would require $2.16 \mathrm{Mcal}$ of $\mathrm{NE}_{\mathrm{G}}$ to achieve that outcome. The same calculation without adjusting for composition relative to maturity would result in a calculated requirement of $2.69 \mathrm{Mcal}$ of $\mathrm{NE}_{\mathrm{G}}$, a $24.5 \%$ higher daily requirement than needed. If the adjustment was not made, the amount of energy provided to the animal over a period of 100 to $300 \mathrm{~d}$ would result in a significant increase in both growth and body fat, as the energy supply would have been in excess of requirements and most likely the protein would not have been adjusted to match the extra energy; therefore, the resulting growth would be energy excess and protein limiting, resulting in over-conditioned heifers. This set of calculations was provided to help the reader understand why these relationships were developed and also to illustrate that prior studies where higher energy intakes were employed to evaluate either prepubertal growth and mammary development (Sejrsen et al., 1982; Harrison et al., 1983; Mäntysaari et al., 1995) or first-lactation milk production outcomes (Little and Kay, 1979; Foldager and Sejrsen, 1987) did not consider anything related to composition or mature size and were primarily focused on faster or slower growth rates to achieve a certain degree of fattening (Swanson, 1960). Focusing solely on higher energy intakes without regard to either the balances between energy and protein or what the optimum weight and composition might be to optimize first-lactation milk yield would lead to heifers that were most likely overconditioned and thus performed similar to any dairy cattle that are overconditioned at calving (Rukkwamsuk et al., 1999; Douglas et al., 2006; Ingvartsen, 2006; Overton, 2011). Additionally, given how energy balance normally works across the growth phase, any heifers that are overconditioned by puberty or pregnancy are most likely always going to be overconditioned through to calving, as they will consistently be in positive energy balance; thus, the degree of adiposity will be maintained and could increase depending on when the heifers become pregnant. Therefore, it is important to ensure that the target growth rate and target age at conception are established early in life and the mature size known and used to adjust the nutrient requirements and supply to minimize the opportunity for overconditioning while maintaining adequate pre- and postbreeding growth rates.

In addition, if pregnancy was delayed for any reason, such as using age instead of BW as the metric, then as the heifers approached calving it is possible they would gain more body condition in the last 2 to 3 mo of pregnancy because they are at a stage of growth where protein retention is low and the ability to retain adipose is quite high. Further, the lack of balance between energy and protein can be exacerbated in the third trimester of pregnancy, as most studies and farms have 1 pregnant group and the increased requirements for protein starting in the third trimester of pregnancy are rarely considered in formulation of requirements (Bell et al., 1992; Bell, 1995; NRC, 2001); thus, with protein-deficient diets and a possible excess of energy, the opportunity to achieve greater body condition before calving is higher. The change in both energy and protein requirements are significant starting at approximately $191 \mathrm{~d}$ of pregnancy, with an increase in ME requirement of 5.1 Mcal and MP requirements of $280 \mathrm{~g} / \mathrm{d}$ (NRC, 2001). These changes in requirements can be confused if the MBW and stage of maturity are not considered; thus, heifers might be fed more energy than needed, which the increase in pregnancy requirements might balance out, but the protein requirements are also higher and it is likely the supply remains unchanged. This provides the potential to reduce heifer growth at the expense of fetal requirements, resulting in heifers that will not meet the BW objectives for optimum first-lactation milk. Under these conditions, a separate group composed of heifers in the third trimester of pregnancy could be considered to ensure the energy and protein requirements for fetal growth, heifer growth, and mammary and colostrum development are met. 


\section{Mammary Development and Milk Yield}

Traditionally, body composition has been overlooked when analyzing the effects of prepubertal growth rates on first-lactation performance. However, just as body composition and obesity influence the performance of mature dairy cattle, those factors are also a crucial determinant of first-lactation heifer performance. The pivotal work by Sejrsen et al. (1982; 1983) describing the effect of high energy intake on mammary development and the relationship with circulating growth hormone linked the relationship between prepubertal growth, mammary development, and future milk yield. The primary outcome of that study was to provide an intuitive mechanism to explain why rapid growth during the prepubertal phase resulted in reduced milk production in the first lactation. The observation of reduced mammary development could be repeated in almost every experiment (Pritchard et al., 1972; Petitclerc et al., 1984; Mäntysaari et al., 1995; Capuco et al., 1995; Meyer et al., 2006a,b). These repeatable observations lead to the conclusion that high energy intakes reduced mammary development through altered hormone status or signaling processes. However, Meyer et al. (2006a,b) were the first to recognize that mammary development was not reduced by high energy intake but rather the time to reach puberty was reduced, which led to progesterone surges that affect estrogen receptors and estrogen levels, reducing allometric mammary growth in the peripubertal period. The primary outcome of this work was to demonstrate that the mammary gland, similar to all other reproductive organs, grows in proportion to the size of the body and at an apparent predetermined rate and not in proportion to nutrient intake during the postweaning, prepubertal phase.

To evaluate whether the time effect associated with the mammary development observed in Meyer et al. $(2006 \mathrm{a}, \mathrm{b})$ was similar to previous studies, the amount of mammary development (measured in milligrams of mammary parenchyma DNA accumulation per day) was determined. Meyer (2005) hypothesized that if the observation was consistent among studies, mammary development should be predictable based on days on treatment. To standardize parenchyma DNA data across studies and to minimize the effect of betweenstudy variation in gland dissection, DNA assay procedures, and so on, it was decided to work in fractions of 100 rather than absolute amounts of parenchyma DNA. For each study, parenchyma DNA of heifers on the restricted nutrient intake (i.e., low daily gain group) was designated as $100 \%$ and parenchyma DNA of heifers on the elevated nutrient intake treatment (i.e., high daily gain group) was designated as some fraction of the low ADG group. Published treatment means were used in all instances. For example, in the case of Sejrsen et al. (1982), the lower rate of gain group had 1,562 mg of parenchyma DNA at harvest; this was set equal to $100 \%$. The high rate of gain treatment heifers had $1,061 \mathrm{mg}$ of DNA, so this was set to $67.9 \%(1,062 / 1,562 \times 100)$.

The average parenchyma DNA accretion rate from the Meyer et al. (2006 a,b) study was also converted from an absolute value to a fractional basis. This fractional accretion rate represented the ADG of parenchyma DNA as a fraction of the maximum DNA at harvest. As physiological age (i.e., BW relative to puberty) influenced the daily parenchyma DNA accretion rate, the weight at harvest would influence the average daily DNA accretion rate a heifer has experienced in her lifetime. For example, a heifer harvested at $250 \mathrm{~kg}$ would have a lifetime average parenchyma DNA daily accretion rate that is greater than a heifer harvested at $350 \mathrm{~kg}$ because the heifer harvested at $350 \mathrm{~kg}$ would have spent a considerable amount of time in the postpubertal isometric growth phase, which would result in reducing her lifetime average parenchyma DNA accretion rate. The heifer harvested at $250 \mathrm{~kg}$ will not have experienced this. Therefore, when calculating the fractional accretion rate from the data of Meyer et al. (2006a,b) for use in predicting mammary development among studies, it was necessary to calculate the average lifetime accretion rate up to the weight in which heifers in the study of interest were harvested.

When predicting total parenchyma DNA in heifers harvested at approximately $350 \mathrm{~kg}$, the calculated lifetime parenchyma DNA accretion rate used all of the data from Meyer et al. (2006a,b), including the 350-kg harvest weight. This was also the case for Sejrsen et al. (1982), Petitclerc et al. (1984), and Capuco et al. (1995); however, Pritchard et al. (1972) and Mäntysaari et al. (1995) harvested their heifers at $250 \mathrm{~kg}$. Therefore, the lifetime average parenchyma DNA accretion rate was calculated using accretion rate data from the harvest weights up to and including the $250 \mathrm{~kg}$ of BW.

The lifetime average fractional parenchyma DNA accretion rates were calculated by setting the parenchyma DNA for the restricted heifers in the Meyer et al. (2006a,b) study at the heaviest desired harvest weight equal to $100 \%$. For example, when calculating the lifetime average fractional DNA accretion rate for heifers harvested at $350 \mathrm{~kg}$, the parenchyma DNA in the 350$\mathrm{kg}$ restricted gain heifers was set to $100 \%$ and this was considered the maximum amount of parenchyma DNA achievable. Parenchyma DNA values from all other harvest weights and from elevated gain heifers were set to some fraction of $100 \%$. The fractional parenchyma DNA accretion rate between consecutive weights was then calculated as the change in percent maximum DNA between 2 consecutive harvest points divided by 
the time between the 2 harvest points. This fractional accretion rate was calculated on an individual heifer basis and averaged by treatment in the same manner as the absolute parenchyma DNA accretion rates discussed above. The average of all 6 harvest weights was taken to represent the lifetime average fractional DNA accretion rate. The average rate for a heifer harvested at $350 \mathrm{~kg}$ was calculated to be 0.205 and $0.236 \%$ per day for elevated and restricted gain heifers, respectively (Meyer, 2005). There was no difference between the 2 levels of nutrient intake $(P=0.61)$, so an average of $0.221 \%$ per day was used. The lifetime average fractional DNA accretion rate for a $250-\mathrm{kg}$ heifer was calculated by setting the parenchyma DNA in the $250-\mathrm{kg}$ restricted heifers to $100 \%$, and this was considered the maximum amount of parenchyma DNA achievable. The average of the first 4 harvest weights was taken to represent the lifetime average fractional parenchyma DNA accretion rate. This average rate for a heifer harvested at 250 $\mathrm{kg}$ was calculated to be 0.318 and $0.368 \%$ per day for elevated and restricted gain heifers, respectively. Again, there was no difference between the 2 levels of nutrient intake $(P=0.49)$, so an average of $0.343 \%$ per day was used (Meyer, 2005).

Using this approach, we predicted normal and dietimpaired prepubertal mammary development using the fractional parenchyma DNA accretion rates described above and the age at harvest in each study. For example, Sejrsen et al., (1982) harvested their high rate of gain heifers at an average of $332.5 \mathrm{~d}$ and their low rate of gain heifers at an average of $454.5 \mathrm{~d}$. Both groups of heifers were harvested at approximately 320 $\mathrm{kg}$, so the lifetime average parenchyma DNA fractional accretion rate of $0.221 \%$ per day was used. This approach predicted that parenchyma DNA at harvest for the high rate of gain heifers would be $73.4 \%$ (332.5 $\mathrm{d} \times 0.221 \%$ per day) of the low rate of gain heifers. The predicted parenchyma DNA for these high rate of gain heifers was therefore $1,146 \mathrm{mg}[1,562 \mathrm{mg}$ (the amount of parenchyma DNA in the low rate of gain heifers) $\times 73.4 \%$ ] and the observed value was 1,062 mg (Sejrsen et al., 1982). Using this approach, the low rate of gain heifers were predicted to be $100.4 \%$ ( 454.5 $\mathrm{d} \times 0.221 \%)$. Those authors reported a $32 \%$ reduction on DNA content on the high rate compared with the restricted gain group, consistent with the predictions $(1,562-1,146=416 / 1,562=0.27)$.

The parenchyma DNA accumulation from Meyer et al. (2006b) was compared with the 5 published studies (Figure 4). In this graph, it appears the majority $\left(\mathrm{R}^{2}=0.82\right)$ of the difference in mammary parenchyma development could be explained by age, due to the high correlation between the predicted and observed parenchyma growth. This suggests that, in all of these studies, elevated energy intake hastened the time to puberty and did not directly reduce parenchyma DNA accumulation. Heifers experienced earlier puberty and the hormonal changes associated with the shift from allometric to isometric growth were responsible for the decrease mammary parenchyma development.

Tissue harvest was the endpoint in most of these studies of mammary development, which precluded evaluation of milk yield. A few studies were found where tissue harvest and pregnancy and milk yield data were collected under similar feeding conditions to evaluate both tissue growth and milk yield heifers in a pair-fed experimental design. The studies with direct comparisons are those of Capuco et al. (1995), Waldo et al. (1998), and Smith (2002). Other studies with similar but sequential study data were from Radcliff et al. $(1997,2000)$. In each of these studies, the authors observed significant changes in mammary development without significant changes in first-lactation milk yield.

Capuco et al. (1995) observed a 52\% decrease in mammary parenchyma development at puberty in heifers fed for higher rates of prepubertal gain, but in the pair-fed animals, no significant difference in milk yield

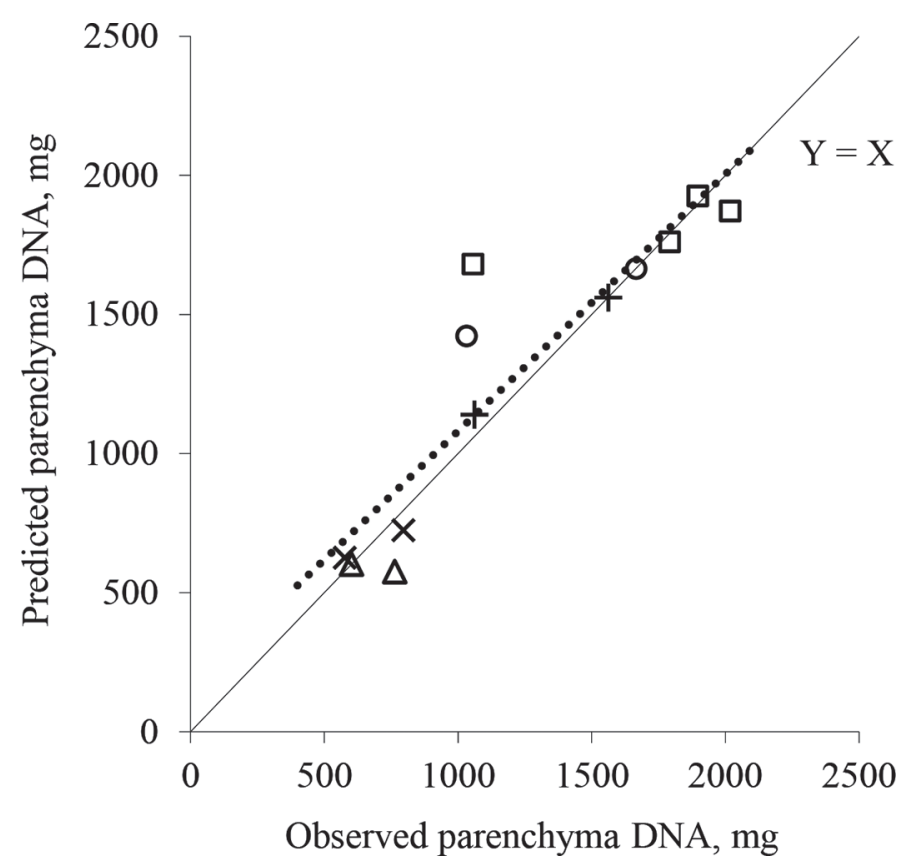

Figure 4. Evaluation of the prediction of normal and diet impaired prepubertal parenchyma development in Holstein heifers. The data points are predicted versus observed. Observed parenchyma DNA accretion data and the average age at slaughter are from published papers [Pritchard et al., $1972(\boldsymbol{\Delta})$; Sejrsen et al., $1982(+)$; Petitclerc et al., $1984(\times)$; Capuco et al., $1995(\square)$; and Mäntysaari et al., 1995 $(\bigcirc)$. Predicted values were generated using the mean daily parenchyma DNA accretion rate determined in Meyer et al. (2006a,b) and the age at slaughter. Slope of predicted verses observed (dotted line) is $0.95, \mathrm{R}^{2}=82 \%(P<0.01)$. The solid line represents unity $(\mathrm{X}=\mathrm{Y})$. 
was observed (Waldo et al., 1998). Smith (2002) fed a calcium salt of CLA with the hypothesis that CLA might reduce adipose tissue deposition in the heifers and, in a harvest study, measured body composition and prepubertal mammary parenchyma development as well as, in pair-fed animals, milk yield. In that study, mammary parenchyma development was reduced by approximately $60 \%$ in heifers fed Ca-CLA; however, those authors found no significant difference in milk yield of the pair-fed heifers where all treatment heifers averaged just over 11,000 kg of milk for the lactation.

In the studies by Radcliff et al. $(1997,2000)$, bST was administered from 125 to $336 \mathrm{~kg}$ of BW to enhance prepubertal mammary development. In the tissue harvest study, mammary development was enhanced approximately $48 \%$ by the use of growth hormone (Radcliff et al., 1997). In a subsequent study with a nearly identical design, milk yield from the prepubertal heifers treated with growth hormone did increase by approximately $5.9 \%$, but that was significant and not highly correlated with the increase in mammary parenchyma development (Radcliff et al., 2000).

Thus, mammary development, measured as DNA content of the parenchyma at puberty, varied by about $100 \%$ ( +48 to $-60 \%)$ with no significant difference in milk yield. This strongly suggests that mammary development when measured as DNA content at puberty was not a good indicator of future milk yield. This is not to dismiss the concept that mammary development is important, but rather to provide opportunity to consider specific cell types instead of gross measurements using DNA as a proxy for cell number (Sinha and Tucker, 1969; Ballagh et al., 2008). More recent data in preweaning heifers suggests that putative stem cells appear to be nutritionally responsive during the milk-fed stage of development, and higher nutrient intakes during this period appears to enhance their proliferation (Soberon and Van Amburgh, 2017). This suggests that any work on mammary development moving forward should focus on specific cell types and not focus on gross measures of cells, especially because the primary cell type measured during prepubertal growth are single layer squamous epithelial cells that form the mammary ducts and are not secretory cells.

\section{Body Composition, Maturity, and Milk Yield}

The difference in body composition among heifers at calving in studies that investigated the effect of AFC on milk yield is difficult to quantify. Based on data describing the productivity of dairy cattle calving at higher-than-desired body condition scores, DMI, milk yield, and postpartum health are usually at greater risk of being compromised (Rukkwamsuk et al., 1999;
Grummer et al., 2004; Ospina et al., 2010). Thus, body composition at calving as it relates to energy balance is as important for first-lactation cattle as multiparous cattle. Further, any difference in body composition of heifers at puberty or pregnancy will most likely be maintained or enhanced, as under most conditions the animals remain in positive energy balance from puberty to calving. Thus, experiments evaluating rapid growth before puberty are potentially measuring the long-term effect of altered body composition through the entire growth phase up to calving.

To further evaluate previous growth and lactation studies, current body composition data and the equations from Van Amburgh and Drackley (2005) and the Dairy NRC (2001) were used to model growth and body composition while taking into consideration stage of maturity of the heifer. Published equations describing energy and protein requirements and body composition to predict body composition at various stages of growth up to calving were used. In addition, equations from Fox, et al. (1999) and the Nutrient Requirements of Beef Cattle (NRC, 1996) were also used to predict nutrient requirements or body composition. The equations were programmed into a spreadsheet to create a model to predict $\mathrm{BW}$ and composition changes. The predictions for body fat percent were evaluated using data from Meyer (2005) and resulted in a $\mathrm{R}^{2}$ of 0.94 (Figure 5). Protein and lean tissue composition were also considered and the protein content was also predicted by the model. The predictions from this model were used in all of the calculations of body composition of heifers immediately postcalving for the studies described in the following paragraphs and in Table 2.

The model was used to evaluate the data from Gibb et al. (1992), where postcalving body composition was available for cows fed to grow at 3 different ADG precalving. A distinctive characteristic of this study was that the MBW of the cattle used could be described as approximately $700 \mathrm{~kg}$, as the study used cattle with 3 and greater lactations. The reported body fat content of cattle grown at the 3 different precalving body growth rates were $18.6,19.4$, and $21.2 \%$. When accounting for the mature weight of the population, the estimates from our model for postcalving body fat content were $18.5,19.5$, and $20.8 \%$ for each of the respective ADG.

Subsequently, several different scenarios were created based on published data to represent studies and potential on-farm conditions that describe various management approaches to decision making for AFC and BW at or postcalving. When prepubertal growth rates were adjusted but heifers were bred by age, the predicted body composition of heifers in each group changed significantly. Using similar assumptions, if calves double their birth weight by $60 \mathrm{~d}$ and grew at $0.7 \mathrm{~kg} / \mathrm{d}$ during 
Table 2. Predicted empty body composition at calving for heifers grown at different prepubertal rates with different mature $\mathrm{BW}^{1}$

\begin{tabular}{lccc}
\hline $\begin{array}{l}\text { Mature } \\
\text { BW, kg }\end{array}$ & $\begin{array}{c}\text { ADG from } \\
\text { 90 to } 350 \mathrm{~kg}, \mathrm{~g} / \mathrm{d}\end{array}$ & $\begin{array}{c}\text { Calculated } \\
\text { body fat, } \%\end{array}$ & $\begin{array}{c}\text { Calculated } \\
\text { body protein, \% }\end{array}$ \\
\hline 700 & 400 & 18.5 & 18.0 \\
700 & 600 & 19.5 & 17.7 \\
700 & 800 & 20.8 & 17.4 \\
600 & 400 & 20.8 & 17.3 \\
600 & 600 & 22.0 & 17.0 \\
600 & 800 & 23.6 & 16.6 \\
550 & 400 & 22.2 & 16.9 \\
550 & 600 & 23.6 & 16.5 \\
550 & 800 & 25.3 & 16.1 \\
500 & 400 & 23.9 & 16.4 \\
500 & 600 & 25.4 & 16.0 \\
500 & 800 & 27.2 & 15.5 \\
\hline
\end{tabular}

${ }^{1}$ The predictions of empty body protein and fat were developed from the growth and body composition equations in Van Amburgh and Drackley (2005), Dairy NRC (2001), and the Beef NRC (1996). The equations were programmed into a spreadsheet to create a model to predict $\mathrm{BW}$ and composition changes.

pregnancy (without the weight of pregnancy), and all heifers were bred at 16 mo for an expected AFC of 25 mo but during prepuberty had ADG of 1, 0.8, or 0.6 $\mathrm{kg}$, they would calve at 30,27 , or $23 \%$ body fat and 14,15 , and $16 \%$ protein, respectively. Data were not available to fully characterize the body composition at calving that provides the most optimum energy balance for first-lactation cattle; however, the difference in body fat from 23 to $30 \%$ should be enough to increase the BCS by at least 1 score, equivalent to $40 \mathrm{~kg}$ of body fat in a 560-kg Holstein heifer. These calculations are consistent with data where heifers were bred to calve at the same age but at different BW; consequently, heavier (fatter) heifers produced less milk during the first lactation (Swanson, 1978).

Again, using a modeling approach and the equations from the Dairy NRC (NRC, 2001), we estimated of the body composition at calving of heifers who were grown at different rates of gain, bred when they had achieved $55 \%$ of their MBW, and had calved at $82 \%$ of their MBW as per current recommendations (Van Amburgh et al., 1998; NRC, 2001). In the base scenario, all animals were assumed to double their birth weight by $60 \mathrm{~d}$ and have an ADG of $0.6 \mathrm{~kg}$ during pregnancy, excluding the weight of the gravid uterus. Three different prepubertal growth rates were used, $0.75,0.64$, and $0.56 \mathrm{~kg} / \mathrm{d}$, which allowed for AFC of 22, 24, and $26 \mathrm{mo}$, respectively. Given these growth rates, the 3 groups of animals were estimated to calve at $25 \%$ body fat and $15 \%$ protein and would not be expected to have differences in milk production, although the animals that calve at 22 mo would be producing milk 4 mo sooner than those set to calve at 26 mo.
Valentine et al. (1987) reported growth rates from 0.18 to $0.94 \mathrm{~kg}$, where AFC ranged from 26.9 mo for the slowest treatment to 22.4 mo for the treatment gaining over $0.9 \mathrm{~kg} / \mathrm{d}$. After calving, the estimated body fat percent for all groups was $22 \%$ and no difference in milk production among any of the groups was observed. These data suggest that if little difference exists in body composition at calving and BW are reasonably similar, DMI, energy balance, and milk yield would not be negatively affected.

Hohenboken et al. (1995), using 4 different Danish breeds, compared 3 different growth rates from 6 wk of life to $300 \mathrm{~kg}$. In their study, all heifers were bred at fixed weight generating $\mathrm{AFC}$ of 29,26 , and 23 mo for heifers raised at ADG of $0.6,0.7$, or $0.9 \mathrm{~kg}$ respectively. These treatments resulted in a predicted body composition of 17 and $25 \%$ body fat and 18 and $16 \%$ protein for calves raised at 0.6 and $0.9 \mathrm{~kg}$, respectively. The treatment heifers with $17 \%$ predicted body fat produced $500 \mathrm{~kg}$ more milk than the group with higher body fat percent. This is consistent with the data describing the potential effect of greater BCS on DMI, energy balance, and milk yield (Garnsworthy and Jones, 1987; Allen et al., 2005; Janovick and Drackley, 2010).

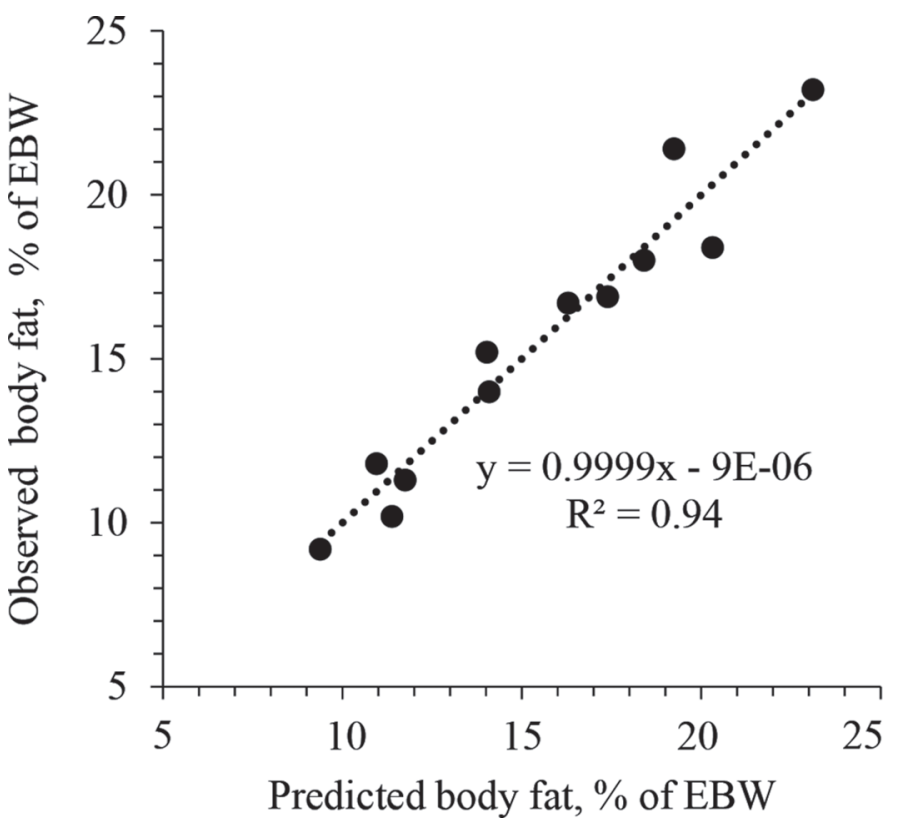

Figure 5. Regression of predicted and observed empty body fat content of dairy calves and heifers at different weights for calves grown at 2 different rates of gain. The predictions of empty body fat were developed from growth and body composition equations in Van Amburgh and Drackley (2005), Dairy NRC (2001), and the Beef NRC (1996). The equations were programmed into a spreadsheet to create a model to predict BW and composition changes. Measured body compositions taken from Meyer (2005). EBW = empty BW. 
Foldager and Sejrsen (1987) concluded that the optimal growth rate of dairy calves between 90 and 350 $\mathrm{kg}$ of live weight should be $0.6 \mathrm{~kg} / \mathrm{d}$. To better describe this, the growth data from Foldager and Sejrsen (1987) were used to predict body composition at calving; however, we had to make assumptions about the MBW of the animals represented and chose a range of mature weights for comparison. Predicted body composition at calving for cattle with MBW from 500 to $700 \mathrm{~kg}$ are presented in Table 2. As mature weight increased, body fat decreased at similar calving weights. The cattle represented in the study appeared to be small-framed cattle with MBW between 500 and $550 \mathrm{~kg}$ (Figure 6). If this study had been performed with larger-framed cattle, conclusions on the effects of growth rate on milk performance might have been different due to the composition of the gain of the animals. Again, depending on the mature size of the cattle, the differences in fat percent translate into differences in BCS of at least 1 unit, and this would have a significant effect on postpartum DMI and milk yield. Milk production in this study differed by $500 \mathrm{~kg}$ in the first $250 \mathrm{~d}$ of lactation, where heifers grown at $0.6 \mathrm{~kg} / \mathrm{d}$ produced 5,100 $\mathrm{kg}$ of milk compared with $4,600 \mathrm{~kg}$ produced by heifers grown at $0.8 \mathrm{~kg} / \mathrm{d}$ during the prepubertal period.

As previously discussed, one of the most crucial and overlooked variables in the effects of growth rate on future performance is mature size. And as previously mentioned, the composition of the gain is dependent on the stage of maturity; therefore, when evaluating growth rates prepuberty, it is important to characterize the growth rates within the stage of physiological maturity. This concept was described for dairy cattle by Fox et al. (1999), who described the percent of MBW at pregnancy (55\%) and postcalving BW (minimum 82\%) necessary to optimize first-lactation milk yield. The key factor in this approach was utilizing the MBW of the herd to adjust for stage of maturity for nutrient requirements instead of using a population value, as MBW can vary among herds due to differences in genetics and environment. In all of the studies conducted on heifers, $\mathrm{ADG}, \mathrm{AFC}$, and lactation before the publication of the Dairy NRC (NRC, 2001), no consideration was given to the mature size of the cattle; thus, most data were not adjusted for stage of maturity and, under those conditions, energy intake was almost always greater than required for the specific objectives of the study (Van Amburgh and Meyer, 2005).

An additional scenario commonly seen in practical conditions is reducing AFC without taking into consideration the physiological maturity of heifers (MBW), necessary to adjust growth rates and achieving target weights. This practice might lead to heifers with a significant growth requirement during lactation, and

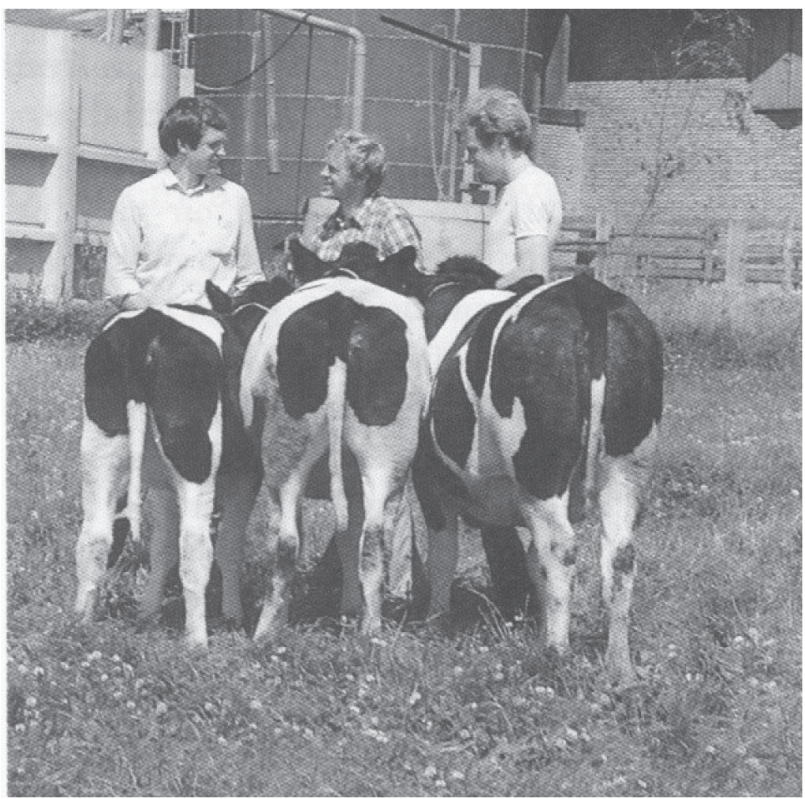

Figure 6. Three 18-mo-old heifers grown at ADG of 400, 600, and $800 \mathrm{~g}$. Live weights were 250, 402, and $540 \mathrm{~kg}$, respectively (photo from Foldager and Sejrsen, 1987; used with permission).

growth will always be a priority for nutrient use as the heifer partition energy away from lactation. This is most likely one of the primary factors affecting milk yield in herds where AFC is identified as an important metric with no discussion of BW, pre- or postpubertal growth rates, or mature size of the herds were considered. Undersized heifers will not only be unable to consume and compete for feed as much as their more mature counterparts, but more of the consumed nutrients will also be partitioned toward growth than for lactation functions (Van Amburgh et al., 1998; Fox et al., 1999). The Cornell Net Carbohydrate and Protein System has a growth function based on current BW, MBW, and time to achieve the expected BW for the next lactation established to predict the amount of nutrients required to meet the target growth to achieve MBW. In a scenario for which herd MBW was $750 \mathrm{~kg}$, a standard diet was balanced using the Cornell Net Carbohydrate and Protein System (Van Amburgh et al., 2015), meeting $100 \%$ of ME, MP, and Met requirements of a first-calf heifer at $82 \%$ of $\mathrm{MBW}(615 \mathrm{~kg})$ and producing $38 \mathrm{~kg}$ of ECM/d with an expected ADG in the first lactation of $0.19 \mathrm{~kg} / \mathrm{d}$; at this stage of maturity, the ME requirement for growth is $2 \mathrm{Mcal} / \mathrm{d}$ and $74 \mathrm{~g} / \mathrm{d}$ of MP, and this requirement would be prioritized over milk yield by the heifer. A contemporary heifer that calved at $72 \%$ MBW (540 kg) was evaluated similarly and expected ADG to meet the BW target for the following lactation was $0.39 \mathrm{~kg} / \mathrm{d}$, more than twice the animal calving at $615 \mathrm{~kg}$, which is an ME requirement for growth of 3.8 
$\mathrm{Mcal} / \mathrm{d}$ and $133 \mathrm{~g} / \mathrm{d}$ for MP. This difference in ME and MP required for growth would come at the expense of milk yield and is equal to approximately $1 \mathrm{~kg}$ of milk/d, not accounting for the DMI difference that would exist between the heifers of at least 1.5 to $2 \mathrm{~kg} / \mathrm{d}$ due to the BW difference. Thus, for every $0.1 \mathrm{~kg}$ of SBW gain required per day, daily ME and MP requirements for growth during lactation would increase by approximately 1 Mcal and $30 \mathrm{~g}$, respectively.

The overall goal of heifer rearing is to provide the management and nutrition that allows for optimum milk yield in the first and subsequent lactations. Research has evaluated many aspects of heifer rearing, but most of the focus has been on prepubertal growth rate and its effects on mammary development. Little to no attention has been placed on the effects of such growth rates on body composition or maturity at calving as it relates to energy balance or growth during the lactation. Transition cow research has unequivocally shown the negative effects of overconditioned cattle at the time of calving on DMI, metabolic problems, and milk yield; these findings also apply to first-lactation heifers. When accounting for predicted body composition at calving, we are able to explain most of the variation in milk production observed in different studies. Body composition explains both the lack of differences in production observed in some studies (Valentine et al., 1987; Waldo et al., 1998) as well as the differences in milk production observed in others (Swanson, 1978; Foldager and Sejrsen, 1987; Hohenboken et al., 1995). Thus, in many studies evaluating mammary development and milk yield, directly or indirectly, the outcome was most likely better predicted by body composition at calving and not mammary development. Moreover, body composition during different growth stages is greatly influenced by mature size. When mature size is not accounted for in ration formulation, energy is often overfed, resulting in greater fat deposition in growing heifers in subtle but significant outcomes.

\section{SUMMARY}

Data presented in this paper support the current growth benchmarks for heifer rearing (Fox et al., 1999; NRC, 2001) to achieve a body composition by calving that does not compromise postpartum energy balance or milk yield and allows for earlier age at first calving. Heifers should be bred between 55 and $60 \%$ of their MBW to achieve a postcalving weight of 82 to $85 \%$ of the MBW of the herd. When these targets are attained, heifers can successfully calve earlier without a negative effect on milk production, with the added benefit of having reduced the length of the nonproductive stage.

\section{ACKNOWLEDGMENTS}

Partial support for the animal studies described in this paper was provided by Milk Specialties Inc. (Eden Prairie, MN) and Land O'Lakes Animal Milk (Arden Hills, MN). This work was also partially funded by the Cornell University Agricultural Experiment Station and USDA-ARS and was a component of NC-1119: Management Systems to Improve the Economic and Environmental Sustainability of Dairy Enterprises.

\section{REFERENCES}

Alderman, G., and B. Cottrill. 1993. Energy and protein requirements of ruminants: An advisory manual prepared by the AFRC Technical Committee on Responses to Nutrients. CAB International, Wallingford, UK.

Allen, M. S., B. J. Bradford, and K. J. Harvatine. 2005. The cow as a model to study food intake regulation. Annu. Rev. Nutr. 25:523547. https://doi.org/10.1146/annurev.nutr.25.050304.092704.

Baldwin, R., K. McLeod, J. Klotz, and R. Heitmann. 2004. Rumen development, intestinal growth and hepatic metabolism in the preand postweaning ruminant. J. Dairy Sci. 87:E55-E65. https://doi .org/10.3168/jds.S0022-0302(04)70061-2.

Ballagh, K., N. Korn, L. Riggs, S. L. Pratt, F. Dessauge, R. M. Akers, and S. Ellis. 2008. Hot Topic: Prepubertal ovariectomy alters the development of myoepithelial cells in the bovine mammary gland. J. Dairy Sci. 91:2992-2995. https://doi.org/10.3168/jds.2008-1191.

Bartlett, K. S., F. McKeith, M. VandeHaar, G. Dahl, and J. Drackley. 2006. Growth and body composition of dairy calves fed milk replacers containing different amounts of protein at two feeding rates. J. Anim. Sci. 84:1454-1467.

Bascom, S. A., R. E. James, M. L. McGilliard, and M. Van Amburgh. 2007. Influence of dietary fat and protein on body composition of Jersey bull calves. J. Dairy Sci. 90:5600-5609. https://doi.org/10 .3168/jds.2007-0004.

Bell, A. W. 1995. Regulation of organic nutrient metabolism during transition from late pregnancy to early lactation. J. Anim. Sci. 73:2804-2819. https://doi.org/10.2527/1995.7392804x.

Bell, A. W., M. B. Rymph, R. Slepetis, W. A. House, and R. A. Ehrhardt. 1992. Net nutrient requirements for conceptus growth in Holstein cows-Implications for dry cow feeding. Page 102 Proc. 1992 Cornell Nutrition Conf. for Feed Manufacturers. Department of Animal Science, Cornell University, Ithaca, NY.

Blome, R. M., J. Drackley, F. McKeith, M. Hutjens, and G. McCoy. 2003. Growth, nutrient utilization, and body composition of dairy calves fed milk replacers containing different amounts of protein. J. Anim. Sci. 81:1641-1655.

Byers, F. M. 1982. Protein growth and turnover in cattle: Systems for measurements and biological limits. Pages 141-165 in Protein Requirements for Cattle: Symposium. Oklahoma State University Division of Agriculture Bulletin MP-109. Oklahoma State University, Stillwater.

Capuco, A. V., J. J. Smith, D. R. Waldo, and C. E. Rexroad. 1995. Influence of prepubertal dietary regimen on mammary growth of Holstein heifers. J. Dairy Sci. 78:2709-2725. https://doi.org/10 .3168/jds.S0022-0302(95)76902-8.

Diaz, M. C., M. Van Amburgh, J. Smith, J. Kelsey, and E. Hutten. 2001. Composition of growth of Holstein calves fed milk replacer from birth to 105-kilogram body weight. J. Dairy Sci. 84:830-842. https://doi.org/10.3168/jds.S0022-0302(01)74541-9.

Douglas, G. N., T. R. Overton, H. G. Bateman II, H. M. Dann, and J. K. Drackley. 2006. Prepartal plane of nutrition, regardless of dietary energy source, affects periparturient metabolism and dry matter intake in Holstein cows. J. Dairy Sci. 89:2141-2157. https: //doi.org/10.3168/jds.S0022-0302(06)72285-8. 
Foldager, J., and K. Sejrsen. 1987. Mammary gland development and milk production in dairy cows in relation to feeding and hormone manipulation during rearing. Pages 102-116 in Research in Cattle Production Danish Status and Perspectives. Landhusholdningsselskabet, Frederiksburg, Denmark.

Fortin, A., S. Simpfendorfer, J. Reid, H. Ayala, R. Anrique, and A. Kertz. 1980. Effect of level of energy intake and influence of breed and sex on the chemical composition of cattle. J. Anim. Sci. 51:604-614. https://doi.org/10.2527/jas1980.513604x.

Fox, D. G., M. E. Van Amburgh, and T. P. Tylutki. 1999. Predicting requirements for growth, maturity, and body reserves in dairy cattle. J. Dairy Sci. 82:1968-1977. https://doi.org/10.3168/jds.S0022 -0302(99)75433-0.

Garnsworthy, P. C., and G. P. Jones. 1987. The influence of body condition at calving and dietary protein supply on voluntary food intake and performance in dairy cows. Anim. Prod. 44:347-353. https://doi.org/10.1017/S0003356100012277.

Garnsworthy, P. C., and J. H. Topps. 1982. The effect of body condition of dairy cows at calving on their food intake and performance when given complete diets. Anim. Prod. 35:113-119. https://doi .org/10.1017/S0003356100000878.

Garrett, W. 1980. Energy utilization by growing cattle as determined in 72 comparative slaughter experiments. Pages 3-7 in Energy Metabolism. 1st ed. Butterworth-Heinemann, Oxford, UK.

Garrett, W. 1987. Relationship between energy metabolism and the amounts of protein and fat deposited in growing cattle. Pages 98-101 in Proc. Energy Metab., 10. EAAP Publ. 32. Rowman \& Littlefield, Lanham, MD.

Gibb, M. J., W. E. Ivingst, M. S. Dhanoa, and J. D. Sutton. 1992. Changes in body components of autumn-calving Holstein-Friesian cows over the first 29 weeks of lactation. Anim. Prod. 55:339-360. https://doi.org/10.1017/S0003356100021036.

Grummer, R. R., D. G. Mashek, and A. Hayirli. 2004. Dry matter intake and energy balance in the transition period. Vet. Clin. North Am. Food Anim. Pract. 20:447-470. https://doi.org/10.1016/j .cvfa.2004.06.013.

Harrison, R. D., I. P. Reynolds, and W. Little. 1983. A quantitative analysis of mammary glands of dairy heifers reared at different rates of live weight gain. J. Dairy Res. 50:405-412. https://doi .org/10.1017/S0022029900032635.

Hoffman, P. C., N. M. Brehm, S. G. Price, and A. Prill-Adams. 1996. Effect of accelerated postpubertal growth and early calving on lactation performance of primiparous Holstein heifers. J. Dairy Sci. 79:2024-2031. https://doi.org/10.3168/jds.S0022-0302(96)76575 $-\mathrm{X}$.

Hohenboken, W. D., J. Foldager, J. Jensen, P. Madsen, and B. B. Andersen. 1995. Breed and nutritional effects and interactions on energy intake, production and efficiency of nutrient utilization in young bulls heifers and lactating cows. Acta Agric. Scand. A Anim. Sci. 45:92-98. https://doi.org/10.1080/09064709509415836.

Ingvartsen, K. L. 2006. Feeding-and management-related diseases in the transition cow: Physiological adaptations around calving and strategies to reduce feeding-related diseases. Anim. Feed Sci. Technol. 126:175-213. https://doi.org/10.1016/j.anifeedsci.2005 .08 .003

Ingvartsen, K. L., and J. B. Andersen. 2000. Integration of metabolism and intake regulation: A review focusing on periparturient animals. J. Dairy Sci. 83:1573-1597. https://doi.org/10.3168/jds .S0022-0302(00)75029-6.

INRA. 1989. Ruminant Nutrition: Recommended Allowances and Feed Tables. R. Jarrige, ed. John Libbey and Co. Eurotext, London, UK.

Janovick, N. A., and J. K. Drackley. 2010. Prepartum dietary management of energy intake affects postpartum intake and lactation performance by primiparous and multiparous Holstein cows. J. Dairy Sci. 93:3086-3102. https://doi.org/10.3168/jds.2009-2656.

Little, W., and R. Kay. 1979. The effects of rapid rearing and early calving on the subsequent performance of dairy heifers. Anim. Sci. 29:131-142. https://doi.org/10.1017/S0003356100012228.
Lofgreen, G., and W. Garrett. 1968. A system for expressing net energy requirements and feed values for growing and finishing beef cattle. J. Anim. Sci. 27:793-806.

Mäntysaari, P., K. L. Ingvartsen, V. Toivonen, and K. Sejrsen. 1995. The effect of feeding level and nitrogen source of the diet on mammary development and plasma hormone concentrations of pre-pubertal heifers. Acta Agric. Scand. A Anim. Sci. 45:236-244. https: //doi.org/10.1080/09064709509413082.

Meyer, M. J. 2005. Developmental, nutritional, and hormonal regulation of mammary growth, steroid receptor gene expression and chemical composition of retained tissues in prepubertal bovine. $\mathrm{PhD}$ Diss. Department of Animal Science, Cornell University, Ithaca, NY.

Meyer, M. J., A. V. Capuco, D. A. Ross, L. M. Lintault, and M. E. Van Amburgh. 2006a. Developmental and nutritional regulation of the prepubertal heifer mammary gland: I. Parenchyma and fat pad mass and composition. J. Dairy Sci. 89:4289-4297. https://doi .org/10.3168/jds.S0022-0302(06)72475-4.

Meyer, M. J., A. V. Capuco, D. A. Ross, L. M. Lintault, and M. E. Van Amburgh. 2006b. Developmental and nutritional regulation of the prepubertal bovine mammary gland: II. Epithelial cell proliferation, parenchymal accretion rate, and allometric growth. J. Dairy Sci. 89:4298-4304. https://doi.org/10.3168/jds.S0022 -0302(06)72476-6.

Mills, J. K., D. A. Ross, and M. E. Van Amburgh. 2010. The effects of feeding medium-chain triglycerides on the growth, insulin responsiveness, and body composition of Holstein calves from birth to 85 kg of body weight. J. Dairy Sci. 93:4262-4273. https://doi.org/10 $.3168 /$ jds.2010-3142.

Moallem, U., G. Dahl, E. Duffey, A. Capuco, D. Wood, K. McLeod, R. Baldwin, and R. Erdman. 2004. Bovine somatotropin and rumenundegradable protein effects in prepubertal dairy heifers: Effects on body composition and organ and tissue weights. J. Dairy Sci. 87:3869-3880. https://doi.org/10.3168/jds.S0022-0302(04)73526 -2 .

Moe, P. W. 1981. Energy metabolism of dairy cattle. J. Dairy Sci. 64:1120-1139. https://doi.org/10.3168/jds.S0022-0302(81)82692 -6 .

NRC. 1996. Nutrient Requirements of Beef Cattle. 7th Rev. Ed. Natl. Acad. Press, Washington, DC.

NRC. 2001. Nutrient Requirements of Dairy Cattle. 7th Rev. Ed. Natl. Acad. Press, Washington, DC.

Ospina, P. A., D. V. Nydam, T. Stokol, and T. R. Overton. 2010. Evaluation of NEFA and $\beta$ - hydroxybutyrate (BHB) in transition dairy cattle in the northeast USA. Critical thresholds for prediction of clinical diseases. J. Dairy Sci. 93:546-554. https://doi.org/ $10.3168 /$ jds.2009-2277.

Overton, T. 2011. Managing the dynamics of feed intake and body condition score during the transition period and early lactation. Pages 204-213 in Proc. Proceedings of the Cornell Nutrition Conference for Feed Manufacturers. 73rd Meeting. Department of Animal Science, Cornell University, Ithaca, NY.

Petitclerc, D., L. T. Chapin, and H. A. Tucker. 1984. Carcass composition and mammary development responses to photoperiod and plane of nutrition in Holstein heifers. J. Anim. Sci. 58:913-919. https://doi.org/10.2527/jas1984.584913x.

Pritchard, D. E., H. D. Hafs, H. A. Tucker, L. J. Boyd, R. W. Purchas, and J. T. Huber. 1972. Growth, mammary, reproductive, and pituitary hormone characteristics of Holstein heifers fed extra grain and melengestrol acetate. J. Dairy Sci. 55:995-1004. https://doi .org/10.3168/jds.S0022-0302(72)85608-X.

Radcliff, R. P., M. J. Vandehaar, L. T. Chapin, T. E. Pilbeam, D. K. Beede, E. P. Stanisiewski, and H. Tucker. 2000. Effects of diet and injection of bovine somatotropin on pre-pubertal growth and firstlactation milk yield of Holstein cows. J. Dairy Sci. 83:23-29. https: //doi.org/10.3168/jds.S0022-0302(00)74850-8.

Radcliff, R. P., M. J. VandeHaar, A. L. Skidmore, L. T. Chapin, B. R. Radke, J. W. Lloyd, E. P. Stanisiewski, and H. A. Tucker. 1997. Effect of diet and bovine somatotropin on heifer growth and mam- 
mary development. J. Dairy Sci. 80:1996-2003. https://doi.org/10 .3168/jds.S0022-0302(97)76143-5.

Reid, J. T., A. Bensadoun, L. S. Bull, J. H. Burton, P. A. Gleason, K. Han, Y. D. Joo, D. E. Johnson, W. R. McManus, O. L. Paldines, J. W. Stoud, H. F. Tyrrell, B. O. H. Van Niekerk, and G. H. Wellington. 1968. Some peculiarities in the body composition of animals. Pages 19-44 in Body Composition in Animals and Man. Natl. Acad. Sci. Pub., Washington, DC

Rico, J. E., V. V. R. Bandaru, J. M. Dorskind, N. J. Haughey, and J. W. McFadden. 2015. Plasma ceramides are elevated in overweight Holstein dairy cows experiencing greater lipolysis and insulin resistance during the transition from late pregnancy to early lactation. J. Dairy Sci. 98:7757-7770. https://doi.org/10.3168/jds.2015 -9519 .

Rukkwamsuk, T., T. A. M. Kruip, and T. Wensing. 1999. Relationship between overfeeding and overconditioning in the dry period and the problems of high producing dairy cows during the postparturient period. Vet. Q. 21:71-77. https://doi.org/10.1080/01652176 .1999.9694997.

Sejrsen, K., J. T. Huber, and H. A. Tucker. 1983. Influence of amount fed on hormone concentrations and their relationship to mammary growth in heifers. J. Dairy Sci. 66:845-855. https://doi.org/ 10.3168/jds.S0022-0302(83)81866-9.

Sejrsen, K., J. T. Huber, H. A. Tucker, and R. M. Akers. 1982. Influence of nutrition of mammary development in pre- and postpubertal heifers. J. Dairy Sci. 65:793-800. https://doi.org/10.3168/jds .S0022-0302(82)82268-6.

Shamay, A., D. Werner, U. Moallem, H. Barash, and I. Bruckental. 2005. Effect of nursing management and skeletal size at weaning on puberty, skeletal growth rate, and milk production during first lactation of dairy heifers. J. Dairy Sci. 88:1460-1469. https://doi .org/10.3168/jds.S0022-0302(05)72814-9.

Sinha, Y. N., and H. A. Tucker. 1969. Mammary development and pituitary prolactin level of heifers from birth through puberty and during the estrous cycle. J. Dairy Sci. 52:507-512. https://doi.org/ 10.3168/jds.S0022-0302(69)86595-1.

Smith, J. M. 2002. Nutritional modulation of growth and development of Holstein heifers. PhD Diss. Department of Animal Science, Cornell University, Ithaca, NY.

Soberon, F., and M. Van Amburgh. 2017. Effects of preweaning nutrient intake in the developing mammary parenchymal tissue. J. Dairy Sci. 100:4996-5004. https://doi.org/10.3168/jds.2016-11826.

Stamey, J. A., N. Janovick, A. Kertz, and J. Drackley. 2012. Influence of starter protein content on growth of dairy calves in an enhanced early nutrition program. J. Dairy Sci. 95:3327-3336. https://doi .org/10.3168/jds.2011-5107.

Swanson, E. W. 1960. Effect of rapid growth with fattening of dairy heifers on their lactational ability. J. Dairy Sci. 43:377-387. https: //doi.org/10.3168/jds.S0022-0302(60)90172-7.

Swanson, E. W. 1978. Heifer performance standards: relation of rearing systems to lactation. Pages $494-511$ Large Dairy Herd Man- agement. C. J. Wilcox, H. H. Von Horn, B. Harris, Jr., H. H. Head, S. P. Marshall, W. W. Thatcher, D. W. Webb, and J. M. Wing, ed.University of Florida Press, Gainesville.

Thorbek, G. 1977. The energetics of protein deposition during growth. Nutr. Metab. 21:105-118. https://doi.org/10.1159/000175757.

Tikofsky, J. N., M. E. Van Amburgh, and D. A. Ross. 2001. Effect of varying carbohydrate and fat content of milk replacer on body composition of Holstein bull calves. J. Anim. Sci. 79:2260-2267. https://doi.org/10.2527/2001.7992260x.

Toullec, R. 1989. Veal calves. Pages 109-119 Ruminant NutritionRecommended Allowances and Feed Tables. R. Jarrige, ed. INRA, London, UK.

Valentine, S. C., R. C. Dobos, P. A. Lewis, B. D. Bartsch, and R. B. Wickes. 1987. Effect of live weight gain before or during pregnancy on mammary gland development and subsequent milk production of Australian Holstein-Friesian heifers. Aust. J. Exp. Agric. 27:195-204. https://doi.org/10.1071/EA9870195.

Van Amburgh, M. E., E. Collao-Saenz, R. J. Higgs, D. A. Ross, E. Recktenwald, E. Raffrenato, L. E. Chase, T. R. Overton, J. K. Mills, and A. Foskolos. 2015. The Cornell Net Carbohydrate and Protein System: Updates to the model and evaluation of version 6.5. J. Dairy Sci. 98:6361-6380. https://doi.org/10.3168/jds.2015 -9378 .

Van Amburgh, M. E., and J. K. Drackley. 2005 Current perspectives on the energy and protein requirements of the pre-weaned calf. Pages 67-82 Calf and Heifer Rearing: Principles of Rearing the Modern Dairy Heifer from Calf to Calving. P. C. Garnsworthy, ed. Nottingham Univ. Press, Nottingham, UK.

Van Amburgh, M. E., D. M. Galton, D. E. Bauman, R. W. Everett, D. G. Fox, L. E. Chase, and H. N. Erb. 1998. Effects of three prepubertal body growth rates on performance of Holstein heifers during first lactation. J. Dairy Sci. 81:527-538. https://doi.org/10.3168/ jds.S0022-0302(98)75604-8.

Van Amburgh, M. E., and M. J. Meyer. 2005. Target growth and nutrient requirements of post- weaned dairy heifers. Dairy calves and heifers integrating biology and management. Nat. Res. Agric. Eng. Sci. 175:54-65.

Waldo, D. R., H. Tyrrell, A. Capuco, and C. Rexroad Jr. 1997. Components of growth in Holstein heifers fed either alfalfa or corn silage diets to produce two daily gains. J. Dairy Sci. 80:1674-1684. https://doi.org/10.3168/jds.S0022-0302(97)76099-5.

Waldo, D. R., A. V. Capuco, and C. E. Rexroad Jr. 1998. Milk production of Holstein heifers fed either alfalfa or corn silage diets at two rates of daily gain. J. Dairy Sci. 81:756-764. https://doi.org/ 10.3168/jds.S0022-0302(98)75632-2.

Williams, C. B., and T. Jenkins. 2003. A dynamic model of metabolizable energy utilization in growing and mature cattle. II. Metabolizable energy utilization for gain. J. Anim. Sci. 81:1382-1389. 